\title{
AS FONTES DO PROJECTO DE NAVEGAÇÃO DE FERNÃO DE MAGALHÃES
}

\author{
Rui Manuel Loureiro \\ Instituto Superior Manuel Teixeira Gomes / \\ CHAM, FCSH - Universidade Nova de Lisboa
}

Resumo: Passam em 2019 cinco séculos sobre a data da partida de Fernão de Magalhães de Sevilha, no comando de uma expedição espanhola que pretendia demandar as fabulosas Ilhas das Especiarias. O trânsfuga português, incompatibilizado com o monarca lusitano D. Manuel I (r.I485-I52I), que lhe recusara a recompensa solicitada pelos muitos anos de serviços dedicados à Coroa lusitana, tinha passado a Espanha dois anos antes, e viera oferecer os seus serviços a Carlos I (r.I516-1556). Apresentava-lhe a proposta de alcançar as ilhas orientais da Insulíndia por uma rota ocidental, evitando navegar nas zonas que o Tratado de Tordesilhas, em I494, decretara de influência portuguesa. Tratava-se, nem mais nem menos, de retomar o projecto indiano de Cristóvão Colombo, mas agora com novas bases, e a partir de um conhecimento mais desenvolvido da geografia da Ásia mais longínqua. Que tipo de fontes poderá Fernão de Magalhães ter utilizado para delinear a sua projectada rota ocidental para o Oriente?

PalaVRas-chave: Fernão de Magalhães; viagem de circum-navegação; descobrimentos ibéricos; literatura de viagens; cartografia.

\section{The Sources of Ferdinand Magellan's Navigation Project}

Aвstract: In 2019, five centuries will have passed since Ferdinand Magellan's departure from Seville, in charge of a Spanish expedition that sought to claim the fabulous Spice Islands. The Portuguese defector, annoyed with the Portuguese monarch Manuel I (r.I485152I), who had refused him the reward requested for many years of dedicated services to the Portuguese Crown, had moved to Spain two years earlier, where he offered his services to Carlos I (r.I5I6-I556). He presented the Spanish king with the proposal of reaching the eastern islands of Indonesia by a western route, avoiding navigation in areas that the Treaty of Tordesillas, signed in I494, had decreed to be of Portuguese influence. This involved quite simply retracing Christopher Columbus's Indian project, but now with new bases and a more developed knowledge of the geography of the Far East. What sources could Ferdinand Magellan have used to trace his planned western route to the East? KeYwords: Ferdinand Magellan; voyage of circumnavigation; Iberian discoveries; travel writing; cartography.

Loureiro, Rui Manuel (2019). «As fontes do projecto de navegação de Fernão de Magalhães». Abriu, 8, 35-67. ISSN: 2014-8526. e-ISSN: 2014-8534. DOI: 10.1344/abriuzor9.8.3. Received: 14/12/2018. Accepted: $3_{1 / 1} / 2019$.

descobrimentos@gmail.com | ORCID o000-0002-4635-4096 Scopus 56971025400 | Universidade Nova de Lisboa (Portugal) 
Fernão de Magalhães baseou-se decerto na sua alargada vivência militar e marítima, acumulada ao serviço de Portugal nos espaços orientais, nos primeiros anos do século XVI, para delinear o projecto de navegar para o Oriente por uma rota marítima ocidental, que em I5I7-1518 apresentaria em Espanha. E recolheu informações orais junto de muitos dos homens com experiência ultramarina com quem se cruzou, ao longo do período lusitano da sua carreira, passado em Portugal e nos estabelecimentos orientais mantidos pela Coroa portuguesa. Mas deverá também ter consultado materiais manuscritos e impressos da mais diversa natureza, que incluiriam não só representações cartográficas de espaços marítimos e terrestres extra-europeus, mas ainda roteiros de navegação, relações de viagem e tratados geográficos. Contudo, não sobreviveram quaisquer listas de manuscritos ou livros impressos que lhe teriam pertencido. $\mathrm{O}$ navegador português, aliás, não goza de fama de letrado, nem aparece associado a qualquer escrito mais desenvolvido, exceptuando um conjunto limitado de cartas e pareceres. Contudo, estes poucos manuscritos que lhe andam atribuídos revelam a letra de um homem habituado a escrever, possivelmente possuidor de uma esmerada cultura literária. Muito se tem escrito sobre Fernão de Magalhães, e estão hoje disponíveis numerosas biografias do célebre navegador português. ${ }^{1}$ Porém, pouco se tem indagado sobre as possíveis fontes orais, literárias, cartográficas que estiveram na origem do projecto magalhânico. Uma tal investigação, evidentemente, terá de acompanhar os principais episódios da sua vida, sobretudo em Portugal, antes da sua passagem a Espanha.

Magalhães terá nascido na região do Porto, na margem sul do rio Douro, como sugerem alguns documentos de arquivos sevilhanos subscritos por ele próprio, e entre estes o seu testamento. ${ }^{2}$ Dois testemunhos portugueses um pouco mais tardios, ambos merecedores de toda a atenção, confirmam esta hipótese. O primeiro testemunho conserva-se num manuscrito de uma biblioteca lisboeta, um curiosíssimo Libro das antiguidades e cousas notaneis de antre Douro e Minho, e de outras m[ui]tas de España e Portugal, da autoria do Dr. João de

- Ver a biografia de Joyner (1992), que apresenta uma excelente síntese da documentação e da bibliografia disponíveis. Merece ainda consulta atenta a obra já antiga do Visconde de Lagoa (1938). E são de consulta indispensável três obras recentes: Castro; Hamon; Thomaz (2007); Garcia (2007); e Gil (2009: 243-348).

${ }^{2}$ Ver a análise desta documentação, alguma dela anteriormente desconhecida, em Gil (2009: 251-252). Sobre a debatida questão da naturalidade de Magalhães, ver Castro; Hamon; Thomaz (2007: 312-315); Barros (2009); e Dantas (2012). 
Barros, composto em I549 (Barros I549). O Dr. João de Barros é um humanista lusitano pouco conhecido, que não deve ser confundido com o seu homónimo João de Barros, o grande cronista português do século XVI. ${ }^{3}$ Conservam-se hoje dois manuscritos desta obra, um deles datado de I548, que foi já publicado, mas que não contém qualquer referência a Fernão de Magalhães (Barros I9I9). É no segundo manuscrito desta obra, que não é exactamente idêntico ao primeiro, que surge a indicação referente à naturalidade do navegador português numa descrição relativa à cidade do Porto. Com efeito, refere o Dr. João de Barros que: «Os homens desta Cidade são polla mor parte muito espertos na arte do marear e se fazem aly grandez naos, e nauios, e daly foi natural o Magalhais que achou outro caminho pera a India que foj homem habilissimo» (Barros 1549: 60 $)$.

O segundo testemunho sobre a naturalidade de Magalhães deve-se ao bem conhecido Fernando Oliveira, um interessante aventureiro e escritor português do século xvi, que geralmente se mostra muito bem informado sobre questões marítimas e náuticas. Por volta de 1570, Oliveira preparou uma cópia comentada do relato de viagem de um anónimo participante da expedição magalhânica, que é conhecido como Viagẽ de Fernão de Magalhães, escripta por hĩ home que foy na cõpanhia. O manuscrito original foi repetidamente publicado.4 Ora, a determinado passo desse relato, Fernando Oliveira escreve que: «Antre os portugueses que descubrirão Maluco foy hum chamado Fernão de Magalhães, natural da cidade do Porto em Portugal. Este era da geração dos Magalhães gente honrada e nobre : e era criado del rey em foro de moço de camara» (Valiére i976: 27-28).

Sabemos, pois, com alguma certeza, onde terá nascido o grande navegador. E, inferindo a partir do percurso posterior, costuma situar-se a data do seu nascimento por volta de I480, mas sem qualquer confirmação documental. Mas, de resto, nada mais se consegue apurar sobre os primeiros anos de vida de Magalhães. ${ }^{5}$ Um testemunho bastante mais tardio, consignado na Conquis-

3 Trata-se de um autor muito pouco estudado; ver Baião (I9I7). Sobre o cronista Barros, ver a recente síntese de Loureiro (2018).

4 Ver a edição de Valiére (1976), que inclui um fac-símile do manuscrito. Sobre Fernando Oliveira, ver Domingues (2004: 36-106).

5 A respeito da família Magalhães, ver Villas-Boas (I998). Pode ver-se uma actualizada síntese da questão, com referências bibliográficas amplas, em Castro, Hamon \& Thomaz (2007: 306-3II). 
ta de las islas Malucas do cronista espanhol Bartolomé Leonardo de Argensola, obra publicada em i609 em Madrid, refere a determinado passo que «Criose Magallanes en seruicio de la Reyna doña Leonor, despues siruiò al Rey don Manuel». 6 D. Leonor de Viseu foi casada com o rei D. João II de Portugal (r. I48I-I495) e era irmã do rei D. Manuel I de Portugal. Não é impossível que Magalhães a tivesse servido; contudo, as investigações realizadas sobre a sua casa, que incluem muitas dezenas de outros nomes, não revelaram qualquer traço do navegador português.7 Mas não é impossível que Magalhães tivesse estado ao seu serviço, pois alguns dos seus familiares foram servidores da casa do duque de Viseu, pai de D. Leonor, o poderoso D. Fernando de Portugal, filho do rei D. Duarte I (r. I433-I438) e sobrinho e herdeiro do infante D. Henrique, conhecido como o Navegador. ${ }^{8}$

Como hipótese de trabalho mais remota - e sabendo das ligações que Magalhães mais tarde manteve com a casa de Bragança — poderia eventualmente admitir-se que houve da parte de Argensola alguma confusão de nomes, e que Fernão de Magalhães fora na realidade criado de outra 'Leonor'. E assim a referência poderia reportar-se a D. Leonor de Mendoza, filha do III duque de Medina Sidonia, que foi a primeira e infortunada mulher de D. Jaime, duque de Bragança, e que em I5ı2 foi morta pelo próprio marido, por suspeitas de adultério. ${ }^{9}$ Em qualquer dos casos, nada se consegue apurar sobre o período de educação e formação inicial de Fernão de Magalhães. Tanto a casa de D. Leonor como a casa dos duques de Bragança eram centros de intensa actividade cultural. Assim, poder-se-á adivinhar, se efectivamente Magalhães serviu em alguma destas casas senhoriais, que teria tido o mesmo tipo de educação de outros jovens fidalgos do seu tempo e condição, que combinavam uma apurada preparação militar com estudos de natureza humanística. ${ }^{10}$

Nos primeiros anos do século XVI, Fernão de Magalhães era 'morador' da casa real, estando pois ao serviço de el-rei D. Manuel I. É nessa qualidade que

${ }^{6}$ Argensola (ı609: 6). Existe uma edição recente: Argensola (20I0). Sobre este cronista espanhol, ver Villiers (2003).

7 Para uma análise da casa de D. Leonor, ver Sousa (2002: 843-872).

8 Ver Villas-Boas (1998). Sobre D. Fernando, ver Lopes (2003).

9 Sobre D. Jaime, ver Rosa (1998). A respeito do controverso episódio, ver Gonçalves (2013).

1o A respeito da casa de D. Leonor, ver Sousa (2002) e Toipa (1994); sobre a casa de Bragança, ver Matos (1956). 
aparece nas listagens de homens que em Março de 1505 embarcam na grande armada de D. Francisco de Almeida, nobre português que ia investido no cargo de primeiro vice-rei do nascente Estado da Índia. ${ }^{11}$ Desde a histórica viagem de Vasco da Gama, em I498, que a coroa portuguesa estava a construir no Oriente um informal império, constituído por dispersos estabelecimentos costeiros, onde eram fundadas feitorias e fortalezas, que eram protegidas por navios poderosamente armados. A partir destas bases, os portugueses pretendiam intervir no tráfico das mais valiosas mercadorias orientais, canalizando-as para a Europa através da recém-aberta rota do Cabo. Anualmente, pois, largavam do Tejo sucessivas armadas, que transportavam de Portugal para a Índia meios técnicos e materiais, assim como renovados contingentes de homens, que iam colaborar na consolidação do Estado da Índia. ${ }^{22}$ Fernão de Magalhães, tal como muitos outros jovens oriundos da pequena nobreza lusitana, embarcava para a Índia em busca de honra e proveito. E durante os oito anos seguintes viajaria extensamente por toda a Ásia marítima, participando nas expedições navais e nas campanhas militares organizados pelas autoridades portuguesas.

Pouco tempo antes da largada desta armada, o impressor de origem alemã Valentim Fernandes, que era precisamente escudeiro da rainha D. Leonor, publicara em Lisboa, em 1502, uma obra à que dera o título de Marco Paulo, na qual reunira um conjunto de relatos de viagens asiáticas em tradução portuguesa. Entre estes destacavam-se o Livro das Maravilhas do viajante medieval Marco Polo, assim como a relação do mercador italiano Nicolò de' Conti, que nas primeiras décadas do século xv jornadeara extensamente pelo Oriente. Na última página da sua edição, Valentim Fernandes proclamava que esta publicação se dedicava especialmente a «auisamẽto daqueles que agora vam pera as ditas Indias». ${ }^{13}$ Ou seja, o impressor alemão fornecia aos homens cultos que partiam para a Índia, numa edição acessível, em língua portuguesa, os mais conceituados — embora desactualizados — relatos europeus sobre o mundo oriental. E incentivava os viajantes a «benignamẽte [...] emẽdar e correger ho que menos acharẽ no escreuer .s. nos vocabulos das prouinçias. regnos. çidades. ylhas. e outras cousas muytas e nõ menos em a distãcia das legoas de hũ̃a terra pera outra» (Polo et. al. I502: XCVIII ${ }^{v}$ ). Assim, não é improvável que o

"A notícia aparece na «Ementa da Casa da Índia», em Rêgo et. al. (I962-I989: I, i Io).

12 A respeito da formação do Estado da Índia, ver Subrahmanyam (I993).

13 Polo et al. (I502: XCVIII ${ }^{v}$ ). Existe uma edição diplomática: Polo et al. (I922). Sobre Valentim Fernandes, ver Jüsten (2007). 
primeiro livro sobre assuntos orientais que passou pelas mãos de Fernão de Magalhães tenha sido precisamente a colectânea Marco Paulo.

A bordo da armada de D. Francisco de Almeida, em I503, viajava o feitor Hans Mayr, representante de interesses mercantis alemães, que escreveu um pormenorizado relato da viagem, descrevendo as diversas escalas efectuadas ao longo da costa oriental de África, nomeadamente em Quíloa, onde foi construída uma fortaleza, e também em Mombaça. ${ }^{14}$ Mas o relato do alemão, que faz parte do chamado Códice Valentim Fernandes - um conjunto de relatos manuscritos reunidos pelo impressor alemão -, não inclui qualquer menção a Magalhães, que não se terá destacado em nenhuma das diversas acções bélicas desencadeadas pelos portugueses. Muito provavelmente, o navegador português viajaria na nau São Bartolomeu, que era capitaneada por João Serrão (Guinote; Frutuoso; Lopes 2002: 86). que poderia ser familiar de Francisco Serrão, um homem que também seguia a bordo da armada e com quem Magalhães haveria de manter um duradouro relacionamento. A armada portuguesa seguiria depois para a costa ocidental da Índia, aportando nomeadamente a Cananor em Outubro de 1505, e um pouco mais tarde a Cochim, cidades portuárias onde o vice-rei D. Francisco de Almeida negociou com as autoridades locais a construção de fortalezas portuguesas. ${ }^{15}$

Nada se consegue apurar sobre as actividades de Magalhães durante o ano de 1506 , mas decerto teria participado nos combates navais contra as forças da cidade de Calecute, nos quais se destacou Francisco Serrão. O cronista português Gaspar Correia, que viveu na Índia a partir de 1512, e que mais tarde escreveria as Lendas da Índia, uma volumosa e documentada história do primeiro meio século de presença portuguesa no Oriente que na época ficou manuscrita, refere-se a «Fernão de Magalhães, que em Calecut fôra muyto ferido». ${ }^{16}$ O episódio, que redundou numa vitória portuguesa sobre a frota de Calecute, merece alguma atenção. ${ }^{17}$ Depois da partida da armada portuguesa de Cochim, com rumo a Lisboa, em Dezembro de 1505, alarmantes notícias chegaram à fortaleza portuguesa de Cananor. Um viajante italiano que vivera em Calecute durante uma temporada, juntou-se aos portugueses, alertando-os para um iminente ataque do Samorim desta cidade indiana, que desde a pri-

${ }_{14}$ Ver este relato em Mayr (1997).

15 Sobre a carreira do primeiro vice-rei, ver Silva (1996).

${ }^{16}$ Correia (1975: II, 28). A respeito de Gaspar Correia, ver Bell (1924)

${ }_{17}$ Sobre este episódio militar, ver Monteiro (I989-I997: I, I37-I42). 
meira hora se revelara hostil à presença lusitana. Em Cananor encontrava-se então D. Lourenço de Almeida, filho do Vice-rei, que de imediato enviou para Cochim, a bordo de um navio comandado por João Serrão, o trânsfuga italiano, que não era outro senão Ludovico de Varthema (2004: 242-245).

Aqui temos mais uma hipótese de trabalho: Fernão de Magalhães, que provavelmente andaria embarcado com João Serrão, travou então conhecimento com o viajante italiano. Varthema regressou pouco depois à Europa, em navios portugueses, e chegado a Itália publicaria em Roma, em I5I0, o Itinerario de Ludovico de Varthema, que conheceu uma ampla difusão em sucessivas edições e traduções. Na sua relação de viagem Varthema relatava as suas alegadas peregrinações até diversas ilhas da Insulíndia, incluindo Samatra, Java, Bornéu, e mesmo Maluco (Varthema 2004: 179-224). Mas estas viagens às partes mais orientais da Ásia muito provavelmente nunca ocorreram, pois suspeita-se hoje que o italiano nunca navegou para leste da Índia. ${ }^{18}$

Anos mais tarde, e de acordo com indicações do cronista espanhol Francisco López de Gómara na sua Historia general de Indias, originalmente publicada em Saragoça em 1552, Fernão de Magalhães, por ocasião da sua entrevista com Carlos I em Valladolid, em 1518, tinha nas mãos «la relación de Luis Berthoman, boloñes, que fue a Bandam, Borney, Bachian, Tidore yotras islas de especias». ${ }^{19}$ Ou seja, depois de voltar a Portugal, o navegador português teve conhecimento de que o seu antigo conhecido, Ludovico de Varthema, publicara um Itinerario em língua italiana — com tradução latina impressa em Milão em I5II, com o descritivo título Novum itinerarium Aethiopiae, Aegypti, utriusque Arabiae, Persidis, Siriae ac Indie intra et extra Gangem -, no qual descrevia detalhadamente as suas andanças orientais. ${ }^{2 \circ}$ E encontrara modo de adquirir essa obra, quem sabe se para mostrar ao monarca espanhol evidências testemunhais das imensas riquezas que se podiam encontrar nas ilhas das especiarias. Curiosamente, o editor Jacob Cromberger, com extrema oportunidade editorial, faria imprimir em Sevilha em I520, numa tradução de Cristóbal de Arcos, a obra de Varthema, com o título Itinerario del Venerable Varon Micer Luis Patricio Romano. ${ }^{21}$

18 Sobre esta questão, ver Barozzi (I996: I59-190).

19 López de Gómara (I965: I, I60). Sobre López de Gómara, ver Jiménez (2001).

${ }^{20}$ Varthema (I5IO). Para uma edição moderna, em tradução francesa, ver Varthema $(2004)$.

${ }^{21}$ Varthema (1520). Sobre a imprensa de Cromberger, ver Griffin (I99I). 
Um documento de Dezembro de 1506 refere que o Vice-Rei português despachara pouco antes para a costa oriental de África uma expedição comandada por Nuno Vaz Pereira, na qual se integrou «Fernam de Magalhaes» (Rêgo I960-1977: X, 356). Durante cerca de um ano este contingente naval deu apoio aos estabelecimentos portugueses de Sofala, Quíloa e Melinde, ajudando a consolidar a presença lusitana naquela região africana, especialmente importante por permitir o acesso ao trato de ouro do império do Monomotapa. ${ }^{22}$ Nada de especial se consegue apurar sobre as actividades de Magalhães, que poderá ter comandado um bergantim. Em Outubro de 1507 Nuno Vaz Pereira estava de regresso a Cochim, de onde efectuou uma jornada à ilha de Ceilão. Embora nada o confirme, não é improvável que Magalhães o acompanhasse, pois era habitual as guarnições portuguesas manterem uma ligação ao mesmo comando durante períodos alargados. Curiosamente, Nuno Vaz Pereira é muito elogiado na relação de viagem que Martín Fernández de Figueroa publicou em Salamanca em I5ı2, com a ajuda editorial de Juan Agüero de Trasmera, e com o título Conquista de la India de Persia E Arabia que fizo la armada del rey don Manuel de Portugal. Como Martín Fernández viajou na companhia do capitão português Nuno Vaz Pereira, é quase certo que se terá cruzado com Fernão de Magalhães, conquanto não lhe faça qualquer referência.. ${ }^{23}$ Mas não é improvável que anos mais tarde o navegador português viesse a adquirir mais este título, escrito por outro dos seus conhecidos.

As primeiras décadas da presença portuguesa no Oriente são minuciosamente relatadas por diversos cronistas mais tardios, que, para além do já referido Gaspar Correia, incluem sobretudo Fernão Lopes de Castanheda e João de Barros. O primeiro, que viveu na Índia entre 1528 e $153^{8}$, de regresso a Portugal publicaria em Coimbra, entre 1551 e 1561, oito livros da sua Historia do descobrimento e conquista da India pelos portugueses. ${ }^{24} \mathrm{O}$ segundo, que desempenhou durante longos anos funções na Casa da Mina e da Índia, em Lisboa, a instituição que supervisionava todos os contactos portugueses com o mundo ultramarino, publicaria nesta cidade três Décadas da Ásia, entre 1552 e 1563 (Barros 1973). Os três cronistas portugueses dedicam alguma atenção a Fernão

${ }_{22}$ Sobre este tema, ver Pearson (1998: 63-100).

${ }_{23}$ Ver uma recente edição em Fernández de Figueroa; Agüero de Trasmera (1999). Trata-se de uma obra raríssima, de que se conhece apenas um exemplar, que foi reproduzido em fac-símile em McKenna (1967).

${ }^{24}$ Ver Castanheda (1979). Sobre Castanheda, ver Avelar (1997). 
de Magalhães, e sobretudo à parte espanhola da sua carreira. Mas nas páginas das suas obras recolhem-se também alguns indícios directos sobre as andanças do navegador português antes de $1517,{ }^{25}$ que analisaremos sumariamente, em articulação com documentos de arquivo.

Em Dezembro de 1508, Fernão de Magalhães embarcou em Cochim na grande armada que o vice-rei D. Francisco de Almeida organizou para combater no litoral noroeste da Índia uma poderosa coligação de diversos potentados indianos, apoiados por um contingente naval egípcio. Terá embarcado no navio do mesmo Nuno Vaz Pereira, que também participou nesta campanha, pois este último nome é destacado na anónima Crónica do descobrimento e primeiras conquistas da Índia pelos Portugueses, escrita na década de I520, mas que na época ficou manuscrita (Albuquerque 1986: 347-353). Como escreve Gaspar Correia, Magalhães «foy no feito dos rumes» (Correia I975: II, 28). designação atribuída à batalha naval de Diu, na qual os portugueses, em Fevereiro de 1509, infligiram uma pesada derrota às forças inimigas, consolidando de forma definitiva o poder lusitano nos mares da Índia, e assegurando a sua capacidade de intervenção no tráfico das mais valiosas mercadorias orientais. ${ }^{26}$ Verificamos, pois, que no espaço de cerca de quatro anos, Fernão de Magalhães circulou incessantemente pelas margens da parte ocidental do Oceano Índico, participando em numerosas expedições navais e combatendo em diversos recontros bélicos. Teve assim oportunidade de adquirir larga experiência náutica e militar, muito embora, do ponto de vista das fontes coetâneas, praticamente não se tivesse destacado do anonimato. Evidentemente, pôde também acumular informações orais sobre o mundo oriental e sobre as imensas riquezas que circulavam incessantemente através de inúmeras rotas mercantis estabelecidas de há longa data, e que os portugueses tentavam a pouco-e-pouco descodificar.

Fernão de Magalhães passaria agora à segunda fase da sua carreira oriental, pois em Agosto de I509 embarcou em Cochim, juntamente com Francisco Serrão, numa expedição comandada por Diogo Lopes de Sequeira. Este destacado fidalgo lusitano, que acabava de chegar de Portugal, trazia instruções explícitas de el-rei D. Manuel I para se dirigir a Malaca, a fim de efectuar um reconhecimento das regiões asiáticas mais orientais. Todas as notícias entre-

${ }_{25}$ Para uma síntese das informações transmitidas pela cronística portuguesa quinhentista sobre Magalhães, com amplas referências bibliográficas, ver Garcia (2007: 227-300).

${ }^{26}$ Sobre este episódio militar, ver Pissarra (2002). 
tanto recolhidas pelos portugueses indicavam que as mais valiosas drogas e especiarias eram oriundas da Ásia do Sudeste, pelo que a coroa lusitana estava especialmente interessada em fundar um entreposto naquela importante cidade portuária da Península Malaia. Durante alguns meses, os portugueses permaneceram em Malaca, negociando um acordo com as autoridades locais, intercambiando mercadorias e, sobretudo, recolhendo informações de natureza estratégica sobre as formações políticas regionais, sobre o movimento mercantil, e sobre a geografia dessas partes da Ásia. Mas na sequência de um inesperado ataque à feitoria lusitana e aos navios portugueses, Diogo Lopes de Sequeira foi obrigado a bater em retirada, deixando em Malaca um grupo de prisioneiros. O cronista Fernão Lopes de Castanheda refere-se repetidamente a Magalhães, que teve um papel muito activo nos diversos confrontos que marcaram a retirada dos portugueses. Este aparece retratado como um experiente homem de armas, que se destaca pela solidariedade manifestada em relação aos seus companheiros, e nomeadamente a Francisco Serrão, que em duas ocasiões de apuros se apressa a socorrer. ${ }^{27}$

De regresso à Índia em finais de I509, referem as crónicas que Fernão de Magalhães embarcou em Cochim logo no início do ano seguinte, num dos três navios que regressavam a Portugal carregados de especiarias e outros produtos orientais. Contudo, duas destas embarcações viriam a naufragar nos chamados Baixos de Pádua, junto às ilhas Lacadivas. O cronista Lopes de Castanheda destaca mais uma vez o papel determinante desempenhado por Fernão de Magalhães, que assumiu a direcção do grupo de náufragos, enquanto os capitães dos navios rumavam a Cananor em botes improvisados, em busca de socorro. Eventualmente, o grupo de portugueses seria resgatado e transportado para Cananor (Castanheda I979: I, 509-5II). João de Barros relata o incidente, e sugere que «Fernam de Magalhães» decidira permanecer com os náufragos por lealdade «a hum seu amigo» de baixa condição social que não fora autorizado a embarcar nos primeiros botes, alusão quase certa a Francisco Serrão. ${ }^{28}$ É provável que Magalhães tivesse perdido neste naufrágio muitas das suas posses, circunstância que o obrigará a continuar no Oriente durante mais alguns anos.

${ }_{27}$ Cf. Castanheda (1979: II, 464-473); e também Barros (I973: III, 39I-423), que não destaca o papel de Magalhães.

${ }^{28}$ Cf. Barros (I973: III, 374-375), que, embora destaque o papel de Magalhães, aproveita para criticar a sua posterior falta de lealdade «com seu Rey, e sua patria». 
Entretanto, Afonso de Albuquerque assumira as funções de governador do Estado da Índia, e estava a desenvolver, ou planeava fazê-lo, operações militares em diversas regiões da Ásia marítima, no sentido de consolidar a presença portuguesa com a aquisição de diversas bases estratégicas. O incipiente império marítimo português, com Albuquerque, começava a adquirir também uma faceta territorial. ${ }^{29}$ Um dos objectivos prioritários era o território de Goa, dependente do sultanato de Bijapur, que foi conquistado pelos portugueses na sequência de uma prolongada campanha militar desenvolvida ao longo de todo o ano de $1510.3^{\circ}$ Goa seria a partir de então a base central do Estado da índia, a designação atribuída à constelação de feitorias e fortalezas que materializavam a presença lusitana no Oriente. Fernão de Magalhães terá decerto participado em algum momento da conquista de Goa, mas nada de especial se consegue apurar nas crónicas da época. Contudo, vários documentos de arquivo se lhe referem. Por um lado, em Setembro de I5ı, Afonso de Albuquerque manda que lhe entreguem em Cananor umas couraças e um corpo de lâminas, sinal de que Magalhães manteria funções militares de algum tipo (Pato; Mendonça I884-I935: I, 287-289). Por outro lado, o navegador lusitano participa em Outubro do mesmo ano, em Cochim, num conselho de «todolos capitães del Rey», reunido por Albuquerque para discutir a conquista de Goa, o que significa que estaria incumbido do comando de algum tipo de embarcação (Pato; Mendonça I884-ı935: II, 6-7).

O parecer de Magalhães é assaz interessante, e revela uma sua curiosa faceta mercantil, que até então permanecera na sombra. O navegador português pronunciou-se contra a utilização no assalto a Goa de «naos de carga», ou seja, de embarcações destinadas ao transporte para Portugal de mercadorias orientais. Na sua opinião, caso estes navios fossem utilizados numa campanha militar de duração incerta, não poderiam cumprir a função mercantil que lhes estava cometida a tempo de largarem de Cochim rumo à Europa em inícios do ano seguinte. Mais ainda, a mobilização dos seus tripulantes para tarefas de guerra impedi-los-ia de dar eficaz cumprimento ao carregamento das mesmas naus: «lhe nom fiqavaa tempo pera empregarem seus dinheiros nem fazerem nada do que lhe era necesairo pera sua viajem» (Pato; Mendonça I884-I935: II,

${ }_{29}$ Sobre Albuquerque e o seu governo do Estado da Índia, ver Pelúcia (2016), e também Garcia (2017).

30 A respeito desta campanha militar, ver Costa; Rodrigues (2008). 
6). Foi já sugerido que este parecer teria desagradado a Albuquerque (Garcia 2007: 24), indispondo-o contra Magalhães, mas tal não é certo, tanto mais que numerosos outros capitães presentes no conselho expressaram idêntica opinião. Parece provável, contudo, que o navegador português estaria associado a empreendimentos de natureza comercial, e teria feito algum investimento na carga de retorno das naus da Índia. Além disso, conservam-se documentos relativos a um conflito derivado de um empréstimo feito por Magalhães em Outubro de I5I0 a um tal Pedro Anes Abraldez (Garcia 2007: 31-37).

Fosse como fosse, Fernão de Magalhães embarcou em meados de I5I I na armada que Afonso de Albuquerque levou a Malaca e que, após fracassadas conversações com as autoridades do sultanato, levou a cabo a conquista daquela cidade malaia em Agosto desse mesmo ano. Com ele embarcou também o seu amigo Francisco Serrão. Albuquerque prosseguia o seu projecto imperial de estabelecer bases fortificadas portuguesas em lugares estratégicos da Ásia marítima, de forma a permitir uma intervenção global e sistemática nos principais tráficos orientais. E Malaca abria as portas para a Insulíndia e também para as regiões que bordejavam o Mar do Sul da China, onde se situavam os locais de produção de muitas das mais valiosas mercadorias orientais procuradas pelos portugueses. Logo após a conquista de Malaca, e depois de iniciada a construção da fortaleza portuguesa, Albuquerque despachou emissários rumo a diversos outros destinos, com vista a assegurar a manutenção da rede de ligações mercantis pacíficas e regulares que tinham até então assegurado a prosperidade daquele entreposto malaio. ${ }^{31}$

Rumo ao arquipélago de Maluco, de onde provinham especiarias tão valiosas como o cravinho, a noz-moscada e a maça, seguiu uma armada de três navios comandada por António de Abreu, que largou de Malaca em finais de I5II.32 Esta expedição tem sido repetidamente analisada, e bastará aqui retomar alguns dados essenciais. António de Abreu, depois de costear a fieira de ilhas que de Java se estende para leste, visitou os arquipélagos de Amboíno e de Banda, para depois regressar a Malaca na segunda metade de I512, com detalhadas informações geográficas, e nomeadamente com os esboços cartográficos e os desenhos panorâmicos preparados durante a viagem pelo piloto Francis-

${ }^{31}$ A respeito dos primeiros tempos da presença portuguesa em Malaca, ver Thomaz (2000).

${ }^{32}$ Ver uma síntese da viagem em Cortesão (1978: 82-88). Ver também Castro; Hamon; Thomaz (2007: 38-59). 
co Rodrigues. 33 O capitão de uma das embarcações era Francisco Serrão, que, na sequência de um naufrágio junto à ilha de Madura, conseguiu atingir as ilhas de Maluco propriamente ditas a bordo de embarcações locais, aí se fixando até à sua morte em I52I. ${ }^{34}$

Especula-se se Fernão de Magalhães teria participado nesta expedição, e à falta de um testemunho inequívoco, podem ser invocados diversos argumentos nesse sentido. Primeiro, nas muitas dezenas de documentos lusitanos produzidos em Malaca durante os anos de I5II e I5I2, que reportam as vicissitudes da fundação e da gestão do novo estabelecimento português, não se encontra qualquer referência a Magalhães, o que poderia significar que ele estava ausente daquela cidade portuária. Depois, Fernão Lopes de Castanheda, numa passagem da sua crónica respeitante às ilhas de Maluco, refere «que ho mesmo Fernão de Magalhães fora testemunha» da viagem de António de Abreu, «tẽdo a certeza õde aquelas ilhas jazião» (Castanheda I979: II, 442). Em terceiro lugar, o já mencionado Fernando de Oliveira referirá mais tarde, no seu relato da viagem de circum-navegação, que Magalhães era um «homẽ entendido na arte da nauegação, e cosmografia, em especial pello que aprendeo de hum seu parente chamado Gõçallo d'Oliueyra, em cuja companhia foy ter aaquella terra [de Maluco]: do qual entendeo a uerdade do sitio daquellas terras» (Valière 1976: 26-27). Ora, em quarto lugar, as crónicas portuguesas quinhentistas referem que Gonçalo de Oliveira, sobre o qual nada de especial se consegue apurar, era precisamente o piloto do navio em que Francisco Serrão partiu de Malaca com rumo às ilhas das especiarias (Castanheda I979: I, 679).

Assim, não parece impossível que Fernão de Magalhães tenha também participado na viagem às ilhas mais orientais da Insulíndia, seguindo à ida no navio de Francisco Serrão, mas regressando desde Banda com António de Abreu. ${ }^{35}$ Aliás, tanto Magalhães como Abreu embarcaram juntos em Malaca, em Janeiro de 1513, com rumo a Cochim, de onde ambos prosseguiram para Lisboa, num dos navios da carreira da Índia que dali largaram pouco depois. ${ }^{36}$

33 Ver estes materiais, bem como uma biografia de Francisco Rodrigues, em Garcia (2008).

34 Sobre la vida de Serrão, ver Lobato (20II).

35 Ver discussão desta questão em Garcia (2007: 23-27), e em Castro; Hamon; Thomaz (2007: 317-319).

${ }^{36}$ Ver Castanheda (1979: I, 742); e Barros (1973: V, 583-605). Com Magalhães viajou também o seu criado Henrique, um malaio originário de Malaca, mas a documentação portuguesa não o refere; ver Gil (2009: 285). 
Por ocasião da sua eventual viagem a Maluco, Magalhães teve oportunidade de conviver com o piloto Francisco Rodrigues, um dos grandes especialistas portugueses da cartografia das regiões mais longínquas da Ásia. Não é impossível que dele tivesse obtido roteiros de navegação e cartas geográficas sobre as ilhas mais orientais da Insulíndia. Entretanto, na sequência do seu regresso a Malaca, poderá ter-se cruzado também com Tomé Pires, que ali exercia funções de feitor, e que estava então a redigir a sua Suma Oriental, o primeiro grande tratado português de geografia oriental. 37 A obra do boticário português, que apenas circularia manuscrita na época, era resultado de uma mente extremamente inquiridora, e continha as mais actualizadas e mais circunstanciadas notícias sobre o arquipélago de Maluco até então disponíveis nos meios cultos europeus (Pires 2017: 222-234).

Talvez Magalhães tenha conseguido obter uma cópia parcial desta obra manuscrita, semelhante à que poucos anos mais tarde circulava em Espanha $\mathrm{e}$ foi adquirida pelo diplomata italiano Andrea Navagero, que a remeteu para Veneza, para o seu amigo Giovanni Battista Ramusio, o conhecido humanista veneziano, que a publicaria anos mais tarde..$^{8}$ Além do mais, Fernão de Magalhães, depois do seu regresso de Malaca, poderia também ter contactado em Cananor com Duarte Barbosa, um funcionário da feitoria portuguesa existente nessa cidade indiana, o qual então preparava um Livro das coisas do Oriente, uma detalhada descrição da Ásia, que depois circulou em manuscrito, e foi também publicada por Ramusio. ${ }^{39}$ Na Biblioteca Nacional de Espanha conserva-se hoje em dia um manuscrito da obra de Barbosa em tradução espanhola, que contém na primeira folha a inscrição «este libro conpuso fernando magallanes portugués piloto lo qual el vio y anduvo».40 É muito provável que se trate de uma cópia de um manuscrito que originalmente estava na posse do navegador português aquando da sua passagem a Espanha. Entretanto, não é

37 Sobre Tomé Pires, ver Loureiro (2002). Para uma recente edição crítica da Suma Oriental, cf. Pires (2017).

${ }^{38}$ Uma tradução parcial da Suma Oriental de Tomé Pires seria publicada em Veneza, em $155^{\circ}$, sem nome de autor, no primeiro volume da compilação de relatos de viagem organizada por Ramusio (1978-1988: II, 537-709).

39 O Livro de Barbosa foi também publicado em I550, no primeiro volume da compilação de Ramusio. Ver Ramusio (1978-1988: II, 7II-780).

$4^{\circ}$ Barbosa (c.1520: I ıor). O manuscrito foi publicado em Blázquez y Delgado Aguilera (1920). Para uma edição crítica, ver Barbosa (1996-2000). 
impossível que este Duarte Barbosa fosse parente dos Barbosa que por esses anos viviam em Sevilha, e com os quais Magalhães se haveria de relacionar poucos anos mais tarde (Gil 2009: I69-ı88 e 279-280).

Fernão de Magalhães encerrava assim o seu segundo período oriental, com redobrada experiência naval e militar, e sobretudo na posse de alargados conhecimentos da geografia e da hidrografia de grandes porções da Ásia marítima. Muito provavelmente, teria visitado algumas das ilhas mais orientais da Insulíndia, na companhia de António de Abreu, adquirindo nessa expedição estratégicos conhecimentos sobre a geografia do arquipélago de Maluco, sobre os produtos exóticos ali disponíveis, e sobre as rotas que de Malaca lá conduziam. Assistira decerto a debates entre os pilotos, cosmógrafos e cartógrafos portugueses sobre a exacta localização do arquipélago de Maluco, pois a extensão para leste das viagens de exploração portuguesas não poderia deixar de colocar na ordem do dia a questão do anti-meridiano de Tordesilhas. Ou seja, até onde poderiam os portugueses navegar e comerciar livremente, sem infringirem os acordos que haviam sido assinados pela coroa lusitana com Espanha em I $494 \cdot{ }^{41}$ Entre os técnicos portugueses de forma alguma existia consenso absoluto, como mais tarde se virá a verificar nas reuniões de Badajoz e Elvas, em I524, sobre o facto de as ilhas de Maluco estarem situadas no hemisfério de influência portuguesa (Albuquerque; Feijó I975). Entretanto, nada de especial se consegue apurar sobre os eventuais proventos adquiridos por Fernão de Magalhães durante o período que medeia entre 1505 e 1513. Porém, tal como muitos dos seus contemporâneos, é absolutamente natural que o navegador português se tivesse dedicado a transacções mercantis, paralelamente à sua carreira de servidor do Estado da Índia.

Chegado a Lisboa em meados de I513, Fernão de Magalhães logo embarcou na grande armada que estava a ser preparada em Lisboa, sob o comando de D. Jaime, duque de Bragança, com vista à conquista de Azamor. El-rei D. Manuel I prosseguia a tradicional política portuguesa de ocupação de posições sólidas no litoral marroquino. ${ }^{22}$ É interessante salientar esta ligação à casa de Bragança, que poderá fazer supor, como foi atrás sugerido, um anterior rela-

41 Sobre a discussão a propósito da localização de Maluco, ver Cerezo Martínez (I994).

$4^{2}$ A respeito desta expedição, ver Costa; Rodrigues (2007). Sobre o papel do duque de Bragança, ver Lavajo (I993). Relativamente à política marroquina de D. Manuel I, ver Racine (20I2). 
cionamento com D. Jaime.43 Na sequência da ocupação de Azamor pela força expedicionária portuguesa, Magalhães permanecerá durante muitos meses naquela praça, conservando-se alguns documentos que dão testemunho da sua presença e actividades no litoral marroquino (Garcia 2007: 27-29). Não é impossível que durante esta expedição Magalhães se tivesse cruzado com o piloto João de Lisboa, que nela terá participado.44 $\mathrm{O}$ encontro é importante por duas razões: por um lado, o piloto português escreveu em I5I4 um Tratado da agulha de marear, que circulou manuscrito, 45 e do qual Magalhães poderia ter obtido uma cópia; por outro lado, João de Lisboa tinha navegado em anos anteriores até à região do Rio da Prata, e seria um dos portugueses mais bem informados sobre a geografia e a hidrografia dessas regiões americanas, como adiante veremos. ${ }^{46}$ De volta a Portugal, Fernão de Magalhães seria acusado de irregularidades no desempenho das funções de quadrilheiro, pelo que foi obrigado a regressar a Marrocos para esclarecer a situação.

De novo em Portugal, Magalhães terá entrado em conflito com el-rei D. Manuel I, por razões essencialmente prosaicas. Como era habitual em homens de armas que retornavam ao reino depois de um mais ou menos prolongado período de serviços ultramarinos, dirigiu ao monarca lusitano, provavelmente em I5I6, um requerimento de aumento da pensão que recebia enquanto fidalgo da casa real portuguesa. Mas, por razões algo obscuras, que parecem estar relacionados ao seu desempenho durante o período marroquino, o pedido foi terminantemente recusado. ${ }^{47}$ Sebastião Álvares, representante português na Andaluzia, escreveria pouco depois que Magalhães pretendia ver a sua moradia mensal acrescentada em «cem rs. mais», ou seja, uma soma bem pouco significativa..$^{8}$ Mas a recusa régia tocara fundo em Magalhães, que aparentemente teria decidido desde logo expatriar-se. Gaspar Correia, num Sumario da chronica del Rey D. João o $3 .^{\circ}$, completado por volta de 1533 e que na época ficou inédito, transmite uma versão sugestiva do rompimento entre o soberano e o

${ }^{3}$ Aliás, Magalhães, após a sua ida para Espanha, manteria ligações com os Bragança estabelecidos em Sevilha; ver Gil (2009: 243-348).

44 A respeito de João de Lisboa, ver Gonçalves (2016).

45 Ver uma edição deste tratado em Albuquerque (198I).

${ }^{4} 6$ Sobre a viagem americana de João de Lisboa, ver Laguarda Trías (1973).

47 Ver Barros (1973: v, 622-63I), que se refere em pormenor a esta questão.

${ }^{4}$ Ramos-Coelho (I892: 432). Sobre a moradia que Magalhães recebia, ver Garcia (2007: 28-30). 
seu indisposto súbdito. Magalhães, perante a recusa de D. Manuel em conceder-lhe a recompensa que achava merecer, pediu-lhe «lyçemça pera hyr buscar vyda omde lhe fyzessem merçe | ao que elrrey respomdeo secamente que nynguem lho nom tolhya». Despeitado, o fidalgo português «se aleuamtou e sahyo da casa omde elrrey estava logo rompemdo o seu aluara de fylhamento e os pedaços deytou da mao» (Correia I992: 200).

Esta versão dos factos não é comprovada por outras fontes. ${ }^{49}$ E parece provável que se teria passado um período de pelo menos um ano entre a recusa de el-rei D. Manuel I recompensar o seu servidor e a decisão deste de rumar a Espanha (Garcia 2007: 28-29). Ao que parece, Magalhães, vivendo em Lisboa, ter-se-á dedicado a empreendimentos de natureza comercial, já que existem referências a verbas por ele recebidas, oriundas de mercadorias trazidas pelas naus da carreira da Índia (Viterbo I988: II, 227). E uma hipótese sugestiva seria Magalhães ter por esses anos mantido relações negociais com Cristóbal de Haro, abastado mercador espanhol que estava estabelecido em Lisboa, onde participava intensamente em negócios ultramarinos. O mercador burgalês estava envolvido no trato da carreira da Índia, as suas embarcações comerciavam na costa ocidental de África, e detinha também interesses em expedições que exploravam o litoral do Brasil..$^{\circ}$ E seria na sua associação com Cristóbal de Haro, muito provavelmente, que Magalhães teria desenvolvido o seu projecto de navegar para as ilhas de Maluco pela via ocidental.

Cristóbal de Haro, que estava ligado a importantes casas comerciais alemãs, e mais concretamente aos poderosos Fugger (Pohle 20I7), pretendia aceder ao lucrativo comércio que os portugueses estavam a desenvolver nas partes mais remotas do Oriente. Mas a coroa portuguesa começara a colocar barreiras à intervenção de mercadores privados no comércio de determinados produtos orientais (Subrahmanyam 1993). E entretanto, Cristóbal de Haro entrara em conflito com el-rei D. Manuel I, no âmbito dos negócios que desenvolvia com a costa da Guiné, e decidiu liquidar os seus assuntos em Portugal e passar a Espanha. A relação entre Haro e Magalhães, aliada ao facto de ambos estarem desavindos com o monarca lusitano, teria dado origem a um projecto inovador: buscar pela via ocidental um caminho para as ithas das especiarias,

49 Ver Castanheda (1979: II, I6I) e Barros (I973: V, 623-628).

$5 \circ$ Sobre Haro, personagem que mereceria um estudo aprofundado, ver Gallez (I99I); Gil (2009: 252-254); Bénat-Tachot (20II), a quem agradeço o envio deste artigo; e também Bénat-Tachot (2015). 
navegando fora da zona de influência que fora reservada a Portugal pelo Tratado de Tordesilhas. Ou, como escrevia o cronista português Fernão Lopes de Castanheda, «por fora da nauegação da India» (Castanheda I979: II, I6I).

Para a consecução deste projecto, três condições básicas se impunham. A primeira delas, obter o patrocínio de uma potência rival. Por isso, Magalhães abandona Portugal, dirigindo-se a Sevilha, para se colocar ao serviço de Carlos I, que aceitará a sugestão de que «erão de seu descobrimento \& conquista as ilhas de Bãda \& as de Maluco», fornecendo ao navegador português todos os meios necessários (Castanheda I979: II, I60). Na versão de Gaspar Correia, Magalhães «vynha a o syrujr como ao mayor primcipe do mundo que hera», pois «sabya mujto da arte esperyca e nas cousas do mar» (Correia I992: 200). Com efeito, quando Fernão de Magalhães passou a Espanha, em Outubro de I5I7, teria uns trinta e tal anos, e era um homem com larga experiência náutica e militar. Efectuara extensas e numerosas viagens marítimas, atravessando o Atlântico e cruzando todos os mares orientais, e participara em repetidas campanhas militares um pouco por todo o Oriente, e também no norte de África. Adquirira um importante cabedal de conhecimentos sobre a navegação oceânica e sobre os espaços geográficos ultramarinos que estavam a ser explorados pelos portugueses. E tivera ocasião de conviver com pilotos, cartógrafos e geógrafos, absorvendo muito do seu saber inovador. A segunda condição seria conseguir financiamento para este empreendimento, quer da parte do soberano espanhol, quer da parte de outros investidores. Por coincidência ou não, Cristóbal de Haro passara igualmente a Espanha em 1517, a partir de onde passou a dirigir os seus negócios ultramarinos, assumindo um lugar de destaque na gestão de expedições marítimas espanholas. E é nesta conjuntura que Haro surge como um dos principais financiadores e impulsionadores do projecto magalhânico.

Faltaria apenas uma terceira condição: A disponibilidade de informações geográficas e cartográficas sobre as rotas e as condições de navegação para o arquipélago de Maluco pela via ocidental. Fernão de Magalhães, já o vimos, possuía um conhecimento especializado e muito actualizado sobre o mundo oriental: as rotas seguidas pelos navios portugueses, os calendários de navegação, os métodos concretos de orientação nas regiões mais orientais da Insulíndia, a configuração física de vastas regiões asiáticas, as características das populações que aí habitavam, os mecanismos comerciais que permitiam a obtenção dos produtos mais exóticos. E muito provavelmente assistira em Malaca a discussões entre pilotos, cosmógrafos e cartógrafos sobre a exacta localização do 
anti-meridiano de Tordesilhas, a linha de demarcação entre as áreas de influência portuguesa e espanhola nos mares orientais. Entre os técnicos portugueses de forma alguma havia unanimidade sobre a situação do arquipélago de Maluco relativamente à tal linha de demarcação. De modo que era defensável, à luz dos conhecimentos e meios técnicos então disponíveis nos meios marítimos lusitanos, que as ilhas das especiarias se situavam no hemisfério espanhol (Brotton 1997: I19-126).

Fernão de Magalhães, para fundamentar devidamente o seu projecto de navegação, necessitaria apenas de reunir informações sobre a geografia do novo mundo americano e sobre as condições de navegação nas suas partes mais meridionais. Ora estas regiões estavam a ser desvendadas há pouco mais de duas décadas por sucessivas expedições portuguesas e espanholas. E Cristóbal de Haro dispunha decerto dessas informações, ou tinha capacidade para as obter de forma expedita, pois não estivera ele associado a diversos empreendimentos exploratórios dirigidos ao Brasil? Com efeito, o mercador burgalês foi um dos financiadores da expedição portuguesa conduzida pelo piloto João de Lisboa que em 15II-1512 viajou até ao Rio da Prata, nas regiões meridionais do Novo Mundo (Laguarda Trías 1973). Assim, através de João de Lisboa, com quem conviveu durante a estadia em Azamor, Fernão de Magalhães teria acesso a um manancial de notícias sobre a configuração da parte meridional das terras americanas - porventura registadas em roteiros ou mapas manuscritos - , e teria também acesso à tese que circulava entre alguns dos participantes ou mentores dessas expedições ao Novo Mundo de que existiria uma passagem para ocidente, e que a distância até às ilhas de Maluco era superável com os meios técnicos navais então disponíveis.

Entre as fontes reunidas por Magalhães para fundamentar o seu projecto de viagem para Oriente por uma rota ocidental poderia estar a Copia der Newen Zeytung aus Presillg Landt, um folheto impresso em Nuremberga em I5I4 ou I5I5, que relatava precisamente a expedição de João de Lisboa ao Rio da Prata poucos anos antes..$^{11} \mathrm{O}$ folheto teria decerto chegado às mãos de Cristóbal de Haro, em Lisboa, através dos seus correspondentes alemães. E de resto seria o mercador burgalês um dos inspiradores da publicação, já que ele próprio é nela mencionado. Ora esta anónima relação adiantava, a determinado passo, que o piloto da expedição — João de Lisboa — defendia que da parte mais me-

51 Para uma tradução espanhola, ver Laguarda Trías (1973: 136-139). 
ridional da costa brasileira «não há mais de 600 milhas até Malaca» e pensava que se poderia «ir e voltar de Lisboa a Malaca em pouco tempo» por uma rota ocidental (Laguarda Trías 1973: 137). Ou seja, estes argumentos poderiam muito bem servir os propósitos de Magalhães.

Estas informações eram repetidas numa outra obra publicada também em Nuremberga no ano seguinte, na secção dedicada à «America» da Luculentissima quaedã terrae totius descriptio, da autoria de Johann Schöner (Van Duzer 20ı०: I09). O cosmógrafo alemão utilizou decerto o panfleto sobre a viagem de João de Lisboa à costa brasileira, e parece reflectir a opinião dominante nos meios eruditos alemães sobre a possibilidade da existência de uma rota ocidental para as ilhas das especiarias. Curiosamente, Schöner foi também autor de um globo terrestre, cujos gomos foram impressos na mesma cidade de Nuremberga em $1515.5^{2} \mathrm{E}$ esse globo representa na parte meridional da América uma passagem marítima ligando o Atlântico ao «Oceanus Orientalis».53 Teria Magalhães, porventura, tido acesso a um exemplar do globo de Johann Schöner, ou a alguma representação cartográfica das concepções do cosmógrafo alemão relativas ao estreito que daria acesso, na parte sul da América, ao mundo oriental? Não se consegue dar uma resposta inequívoca a esta questão, mas os seus contactos com Cristóbal de Haro seriam uma das vias de acesso a este tipo de fontes.

Enfim, outro importante adjuvante do projecto magalhânico seria o cosmógrafo Rui Faleiro, com quem Magalhães estabelecera relações de proximidade em Lisboa, provavelmente depois do seu regresso de Azamor. Faleiro, segundo parece, era criado de D. Nuno Manuel, o almotacé-mor de el-rei D. Manuel I, que se associara a Cristóbal de Haro como patrocinador da expedição de João de Lisboa ao Rio da Prata. ${ }^{44}$ Rui Faleiro passou a Espanha pouco depois de Magalhães, em finais de 1517, e aparece nas capitulações assinadas com Carlos I no ano seguinte como co-responsável pela expedição às ilhas das especiarias. Aparentemente, seria ele o obreiro dos fundamentos cosmográficos do projecto, defendendo a localização do arquipélago de Maluco na área de hegemonia espanhola definida pelo Tratado de Tordesilhas. Mas Rui Faleiro é uma personagem de contornos assaz complexos.55 Fernão Lopes de Cas-

52 Sobre o globo de Schöner, ver Van Duzer (2010).

53 Cf. reprodução do globo em Laguarda Trías (1973: 154-155).

${ }^{54}$ Relativamente a D. Nuno, ver Ferreira (2015).

55 A respeito de Rui Faleiro, ver Mota (1986); e também Gil (2009: 349-387). 
tanheda duvida dos seus conhecimentos técnicos, e refere que ele «faziasse grande astrologo, mas não sabia nada: \& tudo o que fingia que sabia era por hữ spirito familiar que tinha segundo se depois soube» (Castanheda i979: II, I6I). A expressão «spirito familiar» é ambígua. Poderá referir-se à sua crescente loucura, que acabou por determinar que fosse afastado da expedição magalhânica, mesmo nas vésperas da partida. Mas também poderá tratar-se de uma alusão ao seu irmão mais novo, Francisco Faleiro, que também passou a Espanha

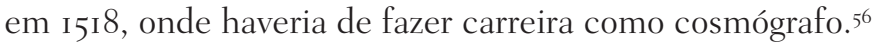

Fosse como fosse, Rui Faleiro entregou a Magalhães, antes deste largar de Sevilha, um Regimento da altura de leste-oeste manuscrito, o qual propunha diferentes formas de determinar a longitude. O problema da longitude, na época de difícil determinação, era crucial para o projecto de Magalhães, já que se tratava de comprovar que o arquipélago de Maluco se situava numa longitude que o colocava decisivamente no hemisfério de influência espanhola. Este manuscrito é mencionado por diversos cronistas posteriores, e nomeadamente por Fernão Lopes de Castanheda, que refere que Rui Faleiro teria entregue a «Fernão de magalhães hữ grande regimento de trinta capitulos, pera que por tres maneyras podesse conhecer a distancia \& deferença que andasse de lestea oeste» (Castanheda I979: II, I6I). Curiosamente, alguns manuscritos do relato de viagem de Antonio Pigafetta, um italiano que participou na expedição como homem de armas, na sua parte final incluem um «Trattato di Navigazione», que aparentemente transcreve partes do Regimento original de Faleiro. ${ }^{57}$

Ao passar a Espanha, em finais de 1517, Magalhães trazia também na bagagem algumas «cartas, e pomas de marear», como escreveu mais tarde o cronista português João de Barros (1973: v, 629). Poderia tratar-se de uma referência ao trabalho cartográfico de Johann Schöner atrás mencionado. Mas mais provavelmente estes exemplares cartográficos basear-se-iam nas mais recentes explorações e especulações da cartografia lusitana..$^{8}$ No fim de contas, ao longo da década de ı5ı diversas expedições portuguesas tinham explorado tanto as regiões mais orientais da Insulíndia, de resto com a contribuição do próprio Magalhães, como as partes mais meridionais do continente americano. E de-

$5^{6}$ Sobre Francisco Faleiro, ver Gil (2009: 389-413); e também Collins (2013).

57 Cf. Pigafetta (1999: 355-382). Sobre este «Trattato», ver Mota (I986: I27-164).

${ }_{58}$ A respeito da cartografia da viagem magalhânica, ver Sandman (2007: IIII-III6); e também Sánchez Martínez (2009). 
certo existiriam em Portugal exemplares cartográficos que registavam essas viagens exploratórias. Parece quase certo que Magalhães teria em seu poder cartas preparadas por Pedro Reinel e por seu filho Jorge Reinel, dois dos cartógrafos portugueses mais activos na época da sua partida de Portugal. ${ }^{59}$ Mas vejamos em primeiro lugar alguns indícios textuais que se referem aos mapas de Magalhães.

A referência mais enigmática encontra-se no relato da primeira circum-navegação da autoria de Antonio Pigafetta. A relação deste viajante italiano foi publicada alguns anos mais tarde em Paris, algures entre 1526 e i536, em tradução francesa condensada, com o título Le voyage et nanigation, faict par les Espaignolz es Isles de Mollucques. Mas conhecem-se diversos manuscritos, em francês e em italiano, mais completos do que a versão impressa. ${ }^{60}$ Pigafetta, a determinado ponto da sua narração, quando os expedicionários buscavam a passagem do Atlântico para o imenso espaço marítimo que logo depois ficaria conhecido como «Pacífico», refere que Magalhães «sabia que tinha de navegar por um estreito muito escondido, pois o tinha visto numa carta náutica do rei de Portugal, a qual carta tinha sido feita por um grande piloto e navegador chamado Martinho da Boémia» (Castro; Hamon; Thomaz 2007: 106). ${ }^{61}$ Martin Behaim, ou Martinho da Boémia, é uma figura algo controversa, que entre as décadas de 1480 e 1500 viveu intermitentemente em Portugal, onde esteve ligado aos meios marítimos e mercantis lusitanos. ${ }^{62}$ Concebeu o célebre globo datado de I492, que anda associado ao seu nome, e do qual ainda hoje sobrevive um exemplar em Nuremberga. Não se lhe conhecem outras produções cartográficas, de modo que é difícil aceitar à letra a declaração de Antonio Pigafetta.

Estaria o viajante italiano, que de resto é um relator bastante rigoroso, a referir-se a um exemplar cartográfico entretanto desaparecido, efectivamente produzido por Martin Behaim durante os seus anos de residência em Portugal? Ou teria cometido algum equívoco no nome do cartógrafo, querendo referir-se antes ao já mencionado globo de Johann Schöner? Pigafetta recebeu

59 Sobre os Reinel, ver Amaral (1995); e também Moreira (2015).

60 A respeito dos relatos impressos da viagem de Magalhães, ver Faria (1975); sobre Pigafetta e a sua obra, ver Pigafetta (1999: 19-353), e também a edição recente Castro; Hamon; Thomaz (2007: 77-26I).

6r Traduzo do francês.

${ }^{62}$ Sobre Behaim, ver Ravenstein (1908) e Pohle (2007). 
decerto esta informação do próprio Fernão de Magalhães, com o qual teve oportunidade de conviver durante longos meses, pois viajava a bordo da capitaina da expedição magalhânica. Assim, parece difícil atribuir a um erro ou equívoco a menção ao cosmógrafo alemão. Magalhães poderia de facto ter consultado em Portugal, nos meios náuticos e cosmográficos ligados à corte de el-rei D. Manuel I, um exemplar cartográfico que seria da autoria de Behaim, ou baseado nas suas especulações geográficas. E nada impede que depois de 1492 as ideias cartográficas de Behaim tivessem evoluído, à medida que surgiam notícias de novas terras visitadas ou descobertas pelas muitas expedições marítimas despachadas de Lisboa e de Sevilha rumo a destinos longínquos. Mas perante a inexistência de outros testemunhos, é difícil aceitar a ideia de uma carta actualizada da parte meridional da América da autoria de Behaim, tanto mesmo que este terá desaparecido em I507, numa altura em que a exploração do litoral brasileiro era ainda incipiente.

Vários cronistas espanhóis posteriores retomam a referência de Pigafetta. O dominicano Bartolomé de Las Casas, que em I5I8 se encontrava em Valladolid e ali se cruzou com Magalhães, escreverá mais tarde, na sua Historia de las Indias, completada na década de $\mathbf{5 6 0}$, mas que na época ficou manuscrita, que Magalhães tinha visto a carta de marear de «un Martin de Bohemia, gran piloto ó cosmógrafo, que estaba en la Tesorería del rey de Portugal». Baseava-se, segundo afirma, na já citada relação de Pigafetta, talvez em alguma cópia manuscrita que lhe tivesse chegado às mãos. Mas acrescentava que o navegador português, para convencer Carlos I da justeza das suas ideias cosmográficas, trazia consigo «un globo bien pintado, en que toda la tierra estaba, y allí señaló el camino que habia de llevar, salvo que el estrecho dejó, de industria, en blanco, porque alguno no se lo saltease».63 A palavra «globo» usada por Las Casas não significaria necessariamente um globo terrestre, pois é pouco provável que Magalhães transportasse consigo um tal artefacto, na época extremamente raro e valioso. ${ }^{64}$ Possivelmente, o cronista dominicano referir-se-ia a algum tipo de planisfério, um globo terrestre planificado, ou talvez mesmo a um globo representado em dupla projecção polar.

Francisco López de Gómara, na sua já citada Historia general de Indias, ao tratar da entrevista de Magalhães com o monarca espanhol, alude também à

63 Casas (I875-1876: IV, 377). Sobre o escritor dominicano, ver Clayton (2012).

${ }^{6}$ A respeito da utilização de globos, na época, ver Dekker (2007). 
«carta de marear que tenía el rey de Portugal, hecha por Martín de Bohemia», baseando-se decerto no relato de Antonio Pigafetta. E acrescentava que naquela carta, segundo ouvira dizer, não figurava qualquer passagem ou estreito na parte meridional da América, «sino el asiento de las Molucas» (López de Gómara I965: I, I60). Nesta versão, desaparece a menção a um globo terrestre. López de Gómara, entretanto, introduz um pormenor interessante na sua narrativa das conversações que tiveram lugar em Valladolid com Carlos I. Para além de apresentar um mapa — aparentemente um planisfério — com a representação das ilhas das especiarias, e um exemplar já atrás referido da obra de Ludovico de Varthema, Magalhães teria também exibido a correspondência que recebera do seu amigo Francisco Serrão, que continuava a residir no arquipélago de Maluco desde 1512 (López de Gómara 1965: I, I60). A referência a Serrão, evidentemente, teria também sido colhida pelo cronista espanhol na narrativa de Pigafetta. ${ }^{65}$ A referência a Behaim é retomada quase com as mesmas palavras por um terceiro cronista espanhol mais tardio, Antonio de Herrera y Tordesillas, na sua Historia general de los hechos de los Castellanos en las islas y tierra firme del mar océano, publicada em Madrid em vários volumes, entre i6or e i6I5. ${ }^{66}$

Mas um outro autor espanhol que escrevia nos primeiros anos do século XVII introduz uma curiosa observação a respeito do exemplar cartográfico que teria sido apresentado por Fernão de Magalhães em Valladolid. Bartolomé Leonardo de Argensola, na sua Conquista de las islas Malucas, refere que o navegador português, aquando da sua passagem a Espanha, trazia consigo «un Planisferio dibuxado por Pedro Reynel»(Argensola ı609: I6). Trata-se da hipótese mais verosímil, que parece ser confirmada por documentação da época da preparação da expedição magalhânica. Magalhães, durante os anos imediatamente anteriores a 1517 , teria travado conhecimento com o luso-africano Pedro Reinel, que em Lisboa exercia funções de cartógrafo, no âmbito da Casa da Mina e da Índia. De alguma forma teria conseguido obter de Reinel um planisfério, que poderia ser muito semelhante a uma obra atribuída a este cartógrafo e ao seu filho Jorge Reinel, datada de cerca de 1519, que é conhecida como Kunstmann IV, cujo original desapareceu, mas de que se conserva uma

${ }_{65}$ Cf. Castro; Hamon; Thomaz (2007: I, 207). Sobre Francisco Serrão, ver Lobato (20II).

${ }^{66}$ Herrera y Tordesillas (I60I: II, 66). Sobre Herrera, ver Cuesta Domingo (1998). 
cópia fidedigna. Este planisfério de grandes dimensões representa o litoral atlântico da América meridional de forma a sugerir uma passagem marítima para o «Mar visto pelos Castelhanos», colocando o arquipélago de Maluco na parte mais ocidental deste mar aberto, numa localização que poderia ser interpretada como pertencendo à área de influência espanhola. ${ }^{67}$

Uma carta de Sebastião Álvares, representante do monarca lusitano em Sevilha, datada de Julho de I519, nas vésperas da partida da expedição magalhânica daquela cidade, confirma o envolvimento de Pedro Reinel e do seu filho Jorge na preparação das cartas utilizadas por Magalhães. Com efeito, Álvares escrevia a el-rei D. Manuel I que num encontro com o navegador português vira as ilhas de Maluco representadas numa "poma carta que ca fez o filho de Reynell, a qual nom era acabada quando caa seu pay veo por ele; e seu pay acabou tudo; e pos estas terras de Maluco». A partir deste mapa-padrão produzido pelos Reinel pai e filho, Magalhães encarregara outros dois cartógrafos, o português Diogo Ribeiro e o espanhol Nuño García de Toreno, de produzirem «todallas cartas» necessárias para a viagem que estava prestes a iniciar-se. ${ }^{68}$

A informação de Sebastião Álvares é algo enigmática. Aparentemente, o jovem Jorge Reinel estava em Sevilha a trabalhar para Magalhães, desenhando cartas para a expedição em preparação. A expressão «poma carta» referir-se-á decerto a um planisfério. Faz sentido o mais jovem Reinel ter sido atraído a Sevilha pelas notícias de que Magalhães estaria a recrutar especialistas que pudessem contribuir para a concretização do seu projecto. O pai, Pedro Reinel, viera a Sevilha em busca do filho, para levá-lo de volta a Portugal. Mas entretanto completou um dos mapas que estava a ser preparado, acrescentando-lhe as ilhas das especiarias. O que parece fazer menos sentido, pois estaria a colaborar num empreendimento que manifestamente prejudicava os interesses ultramarinos da coroa lusitana. A única explicação possível para esta atitude de Pedro Reinel seria a existência de fortes laços de amizade e solidariedade para com Magalhães. Posteriormente, ambos os Reinel teriam regressado a Portugal, continuando em Lisboa a desempenhar oficialmente as funções de cartógrafos.

67 Ver reprodução e comentário em Kupčik (2000: 4I-47).

68 Ramos-Coelho (I892: 434). Sobre Ribeiro, ver Vigneras (I962); sobre Toreno, ver Sanchéz (2013). 
Pedro e Jorge Reinel foram indubitavelmente os cartógrafos essenciais do projecto de Fernão de Magalhães. Foram eles que desenharam o planisfério com o qual o navegador português conseguiu convencer o rei Carlos I a apoiar a sua proposta de navegar para as ilhas das especiarias pela rota ocidental, e que seria semelhante ao chamado Kunstmann IV. E pelo menos dois outros trabalhos cartográficos dos Reinel podem ser associados à primeira viagem de circum-navegação. Por um lado, uma carta do Oceano Índico datada de cerca de I5I7, que anda atribuída a Pedro Reinel, já desaparecida, mas de que se conserva uma cópia fidedigna em Paris. Neste exemplar cartográfico aparece uma representação muito detalhada das ilhas da Insulíndia, reflectindo as mais recentes viagens portuguesas de exploração naquelas regiões asiáticas. ${ }^{69}$ Por outro lado, uma carta em projecção polar, representando o hemisfério austral, que se conserva em Istambul, e anda também atribuída a Pedro Reinel, sendo datada de cerca de I522. Este tipo de carta revelaria de forma clara a possibilidade de atingir a Insulíndia pela via ocidental, contornando o continente americano. Poderia tratar-se de uma «poma carta» copiada de um dos planisférios produzidos em Sevilha pelos Reinel para Magalhães. $7^{\circ}$

Fernão de Magalhães, pudemos constatá-lo, possuía um conjunto alargado de cartas, produzidas pelos mais especializados cartógrafos portugueses do seu tempo, Pedro e Jorge Reinel. Dispunha de diversos escritos técnicos sobre a arte de navegar, subscritos por pilotos como João de Lisboa e por cosmógrafos como Rui Faleiro. Como escreveu o cronista João de Barros, o navegador português «sempre andava com Pilotos, Cartas de marear, e altura de Leste, Oeste» (Barros 1973: v, 627). Era, de facto, um homem extremamente bem informado sobre questões náuticas e cartográficas. E, como tivemos ocasião de constatar, conhecia muitos dos escritos dedicados à geografia dos espaços ultramarinos que no seu tempo estavam em circulação. Pudera talvez contactar com os mais destacados noticiaristas da geografia asiática, Ludovico de Varthema, Martín Fernández de Figueroa, Tomé Pires e Duarte Barbosa. E tinha decerto conhecimento das novidades editoriais que em Portugal e em Espanha eram dedicadas aos mundos extra-europeus. Navegara demoradamente

69 Ver reprodução e comentário em Kupčik (2000: I30-I35).

70 A respeito deste curioso mapa, ver Destombes (I955); e também Couto (20I3). 
pelos mares orientais, podendo mesmo ter visitado as ilhas de Maluco. Comandara homens e navios em numerosas expedições bélicas. Recolhera informações detalhadas, e em primeira mão, sobre as viagens portuguesas que haviam demandado o litoral da América meridional. Insatisfeito com o seu monarca, estava disposto a abandonar Portugal e a oferecer os seus serviços a Carlos I. Contava à partida com o apoio do riquíssimo mercador burgalês Cristóbal de Haro. Enfim, estavam reunidas todas as condições para avançar com o seu projecto de atingir as ilhas das especiarias pela via ocidental, ao serviço de Espanha, o qual havia sido profundamente meditado, e também discutido com especialistas das mais diversas áreas.

\section{BIBLIOGRAFIA}

Albuquerque, Luís de (1981). "O "Tratado da agulha de Marear" de João de Lisboa; reconstituição do seu texto, seguida de uma versão francesa com anotações». Revista da Universidade de Coimbra, 29, I29-162.

Albuguerque, Luís de (ed.) (ig86). Crónica do descobrimento e primeiras conquistas da Índia pelos Portugueses. Lisboa: Imprensa Nacional - Casa da Moeda.

Albuquerque, Luís de; Feijó, Rui Graça (198I). «Os pontos de vista de D. João III na junta de Badajoz-Elvas». Avelino Teixeira da Mota (ed.). A Viagem de Fernão de Magalhães e a Questão das Molucas. Lisboa: Junta de Investigações do Ultramar, 527-545. Amaral, Joaquim Ferreira do (1955). «Pedro Reinel me fez». À Volta de um Mapa dos Descobrimentos. Lisboa: Quetzal Editores.

Argensola, Bartolomé Leonardo de (I609). Conquista de las islas de Maluco. Madrid: Alonso Martín.

Argensola, Bartolomé Leonardo de (2010). Conquista de las Islas Malucas. Ed. Glória Cano. Madrid: Miraguano Ediciones; Ediciones Polifemo.

Avelar, Ana Paula (1997). Fernão Lopes de Castanheda: Historiador dos Portugueses na Índia ou Cronista do Governo de Nuno da Cunha? Lisboa: Edições Cosmos.

BaIÃo, António (1917). Documentos inéditos sobre João de Barros, sobre o escritor seu homónimo contemporâneo, sobre a família do historiador e sobre os continuadores das suas «Decadas». Coimbra: Imprensa da Universidade.

Barbosa, Duarte (c. 1520). Descripción de los reinos, costas, puertos e islas que hay desde el Cabo de Buena Esperanza hasta los Leyquios. Biblioteca Nacional de España, Res. 47 [em linha] [2 setembro 2018] <http://bdh.bne.es/bnesearch/detalle/ bdhoo002I4I3I >.

Barbosa, Duarte (1996-2000). O Livro de Duarte Barbosa. Ed. Maria Augusta da Veiga e Sousa. Lisboa: Instituto de Investigação Científica Tropical. 
Barozi, Pietro (1996). Ludovico De Varthema e il suo «Itinerario». Roma: Società Geografica Italiana.

Barros, Amândio Morais (2009). A Naturalidade de Fernão de Magalhães. Porto: Edições Afrontamento.

BARROS, João de (1549). Libro das antiguidades e cousas notaueis de antre Douro e Minho, e de outras m[ui]tas de España e Portugal. Biblioteca Nacional de Portugal, Códice 216, [em linha] [2 setembro 2018] <http://purl.pt/26460>.

Barros, João de (1919). Geographia d'Entre Douro e Minho e Trás-os-Montes. Ed. João Grave et. al. Porto: Biblioteca Pública Municipal.

Barros, João de (1973). Da Ásia. Ed. Nicolau Pagliarini. Lisboa: Livraria Sam Carlos. Bell, Audrey (1924). Gaspar Corrêa. Londres: Oxford University Press.

BéNAT-TACHOt, Louise (201I). «Cristóbal de Haro, un marchand judéo-convers entre trois mondes au XVI ${ }^{e}$ siècle ou le défi d'une 'globalisation' avant l'heure». Esther Benbassa (ed.). Les Sépharades: Histoire et culture du Moyen Âge à nos jours. Paris: Presses de l'Université Paris-Sorbonne, I35-160.

BÉnAT-TACHOt, Louise (20I5). «La Corogne et Séville: les horizons de l'expansion maritime espagnole (I492-1550)».e-Spania, 22, [em linha] [2 setembro 2018] <http:// journals.openedition.org/e-spania/25043>.

Blázquez y Delgado Aguilera, Antonio (ed.) (I920). Descripción de los reinos, costas, puertos e islas que hay desde el Cabo de Buena Esperanza hasta los Leyquios. Madrid: Establecimiento Tipográfico Torrent y Compañia.

BвоттоN, Jerry (1997). Trading Territories: Mapping the early modern world. Londres: Reaktion Books.

Casas, Bartolomé de Las (1875-1876). Historia de las Indias. Ed. Marqués de la Fuensanta del Valle e José Sancho Rayon. Madrid: Imprenta de Miguel Ginesta.

Castanheda, Fernão Lopes de (1979). História do Descobrimento e Conquista da Índia pelos Portugueses. Ed. Manuel Lopes de Almeida. Porto: Lello \& Irmão.

Castro, Xavier; Hamon, Jocelyne; Thomaz, Luís Filipe (ed.) (2007). Le voyage de Magellan: La relation d'Antonio Pigafetta et autres témoignages. Paris: Éditions Chandeigne.

Cerezo Martínez, Ricardo (I994). «El Meridiano y el Antimeridiano de Tordesillas en la Geografía, la Náutica y la Cartografía». Revista de Indias, 54-202, 509-542.

Clayton, Lawrence A. (2012). Bartolomé de las Casas: A Biography. Nova Iorque: Cambridge University Press.

Collins, Edward (2013). «Francisco Faleiro and Scientific Methodology at the Casa de la Contratación in the Sixteenth Century». Imago Mundi, 65-I, 25-36.

Correia, Gaspar (1975). Lendas da Índia. Ed. Manuel Lopes de Almeida. Porto: Lello \& Irmão.

Correia, Gaspar (1992). Crónicas de D. Manuel e de D. João III (até 1533). Ed. José Pereira da Costa. Lisboa: Academia das Ciências de Lisboa. 
Contesão, Armando (ed.) (r978). A Suma Oriental de Tomé Pires e o Livro de Francisco Rodrigues. Coimbra: Acta Universitatis Conimbrigensis.

Costa, João Paulo Oliveira; Rodrigues, Vítor Luís Gaspar (2007). A Batalha dos Alcaides, I5I4: No apogeu da presença portuguesa em Marrocos. Lisboa: Tribuna da História.

Costa, João Paulo Oliveira; Rodrigues, Vítor Luís Gaspar (2008). Conquista de Goa, I5IO-I5I2. Lisboa: Tribuna da História.

Couto, Dejanirah (2013). «Autour du globe? La carte Hazine ${ }^{\circ}{ }^{\text {I } 825}$ de la bibliothèque du Palais de Topkapi, Istanbul». Cartes \& Géomatique, 216, I19-134.

Dantas, Irene da Silva (2012). Entre Memórias: a questão da naturalidade de Fernão de Magalhães. Braga: Universidade do Minho.

Cuesta Domingo, Mariano (i998). Antonio de Herrera y su obra. Segovia: Colegio Universitario de Segovia.

Dekker, Elly (2007). «Globes in Renaissance Europe». David Woodward (ed.). History of Cartography. Volume Three: Cartography in the European Renaissance (Part I). Chicago; Londres: The University of Chicago Press, I35-I73.

Destombes, Marcel (1955). «The Chart of Magellan». Imago Mundi, I2-I, 65-88.

Domingues, Francisco Contente (2004). Os Navios do Mar Oceano: Teoria e empiria na arquitectura naval portuguesa dos séculos XVI e XVII. Lisboa: Centro de História da Universidade de Lisboa.

FARIA, Francisco Leite de (I975). «Primeiras relações impressas sobre a viagem de Fernão de Magalhães». Avelino Teixeira da Mota (ed.). A Viagem de Fernão de Magalhães e a Questão das Molucas. Lisboa: Junta de Investigações do Ultramar, $47 \mathrm{I}-5 \mathrm{I} 8$.

Fernández de Figueroa, Martín; Agüero de Trasmera, Juan (i999). Conquista de las Indias de Persia e Arabia que hizo la armada del rey don Manuel de Portugal. Ed. Luis Gil. Valladolid: Universidad de Valladolid.

Ferreira, Susannah Humble (2015). The Crown, the Court and the Casa da India: Political Centralization in Portugal I479-I52 I. Leiden; Boston: Brill.

Gallez, Paul (i99i). Cristobal de Haro: Banqueros y Pimenteros en busca del Estrecho magallánico. Bahía Blanca: Instituto Patagónico.

Garcia, José Manuel (2007). A viagem de Fernão de Magalhães e os portugueses. Lisboa: Editorial Presença.

Garcia, José Manuel (2008). O Livro de Francisco Rodrigues: O Primeiro Atlas do Mundo Moderno. Porto: Editora da Universidade do Porto.

Garcia, José Manuel (20I7). O Terrivel: A Grande Biografia de Afonso de Albuquerque. Lisboa: A Esfera dos Livros.

GiL, Juan (2009). El exilio portugués en Sevilla: De los Braganza a Magallanes. Sevilha: Fundación Cajasol. 
Gonçalves, António Manuel (2016). «Lisboa, João de». Francisco Contente Domingues (ed.). Dicionário da Expansão Portuguesa, I415-1600. Lisboa: Círculo de Leitores, 64I-644.

Gonçalves, Maria Paula Anastácio (2013). A Senhora Duquesa e o Pajem: Um Caso de Adultério na Aristocracia Quinhentista. Lisboa: Chiado.

Griffin, Clive (I99I). Los Cromberger: La historia de una imprenta del siglo xVI en Sevilla y Méjico. Madrid: Ediciones de Cultura Hispánica.

Guinote, Paulo; Frutuoso, Eduardo; Lopes, António Lopes (2002). As Armadas da Índia, I497-1835. Lisboa: Comissão Nacional para as Comemorações dos Descobrimentos Portugueses.

Herrera y Tordesillas, Antonio de (I60I-I6I5). Historia general de los hechos de los castellanos en las Islas i tierra firme del Mar oceano. Madrid: Juan Flamenco.

Jiménez, Nora Edith (200I). Francisco López de Gómara: Escribir historias en tiempos de Carlos V. Zamora (Michoacán): El Colegio de Michoacán; Instituto Nacional de Antropología e Historia.

Joyner, Tom (1992). Magellan. Camden, ME: International Marine Publishing.

Jüsten, Helga Maria (2007). Valentim Fernandes e a literatura de viagens. Lagos: Câmara Municipal de Lagos.

KuPČIK, Ivan (2000). Münchner Portolankarten: Kunstmann I-XII und zehn weitere Portolankarten / Munich Portolan Charts: Kunstmann I-XII and Ten Further Portolan Charts. Munique; Berlim: Deutscher Kunstverlag.

LagoA, Visconde de (1938). Fernão de Magalhães (A sua vida e a sua viagem). Lisboa: Seara Nova.

Laguarda Trías, Rolando A. (1973). El predescubrimiento del Río de la Plata por la expedición portuguesa de I5II-1512. Lisboa: Junta de Investigações do Ultramar.

Lavajo, Joaquim Chorão (1993). «D. Jaime de Bragança e a epopeia de Azamor». Callipole, I, 9-19.

Lobato, Manuel (20II). «A Man in the Shadow of Magellan: Francisco Serrão, the First European in the Maluku Islands (I5II-I52I)». Revista de Cultura / Review of Culture, 39, 103-120.

Lopes, Sebastiana Alves Pereira (2003). O Infante D. Fernando e a nobreza fundiária de Serpa e Moura (I453-I470). Beja: Câmara Municipal de Beja.

López de Gómara, Francisco (1965). Historia General de las Indias. Ed. Pilar Guibelelde e Emiliano M. Aguilera. Barcelona: Iberia.

Loureiro, Rui Manuel (2002). «O Sudeste Asiático na Suma Oriental de Tomé Pires». Revista de Cultura / Review of Culture, 4, 107-123.

Loureiro, Rui Manuel (2018). «Revisitando as Décadas da Ásia: Algumas observações sobre o projecto historiográfico de João de Barros».e-Spania, n. 30, [em linha] [2 setembro 20I8] <http://journals.openedition.org/e-spania/27836>. 
Matos, Luís de (1956). A Corte literária dos duques de Bragança no Renascimento. Lisboa: Fundação da Casa de Bragança.

Mayr, Hans (I997). «Viagem e cousas de dom Francisco viso rey da Jndia». José Pereira da Costa (ed.). Códice Valentim Fernandes. Lisboa: Academia Portuguesa da História, 344-36r.

McKenna, James B. (1967). A Spaniard in the Portuguese Indies: The Narrative of Martín Fernández de Figueroa. Cambridge (Massachusetts): Harvard University Press.

Monteiro, Armando Saturnino (I989-I997). Batalhas e Combates da Marinha Portuguesa. Lisboa: Livraria Sá da Costa.

Moreina, Rafael (20I5). «Pedro e Jorge Reinel (at.1504-60): Dois cartógrafos negros na côrte de D. Manuel de Portugal (I495-I52I)». Terra Brasilis, 4, [em linha] [2 setembro 20I8] <https://journals.openedition.org/terrabrasilis/I209>.

Mota, Avelino Teixeira da (1986). O Regimento da Altura de Leste-Oeste de Rui Faleiro: Subsídios para o estudo náutico e geográfico da viagem de Fernão de Magalhães. Lisboa: Edições Culturais da Marinha.

Pato, R. A. Bulhão; MendonçA, Henrique Lopes (ed.) (i884-1935). Cartas de Afonso de Albuquerque seguidas de documentos que as elucidam. Lisboa: Academia das Ciências de Lisboa.

Pearson, Michael N. (1998). Port Cities and Intruders: The Swahili Coast, India, and Portugal in the Early Modern Era. Baltimore; Londres: The Johns Hopkins University Press.

Pelúcia, Alexandra (20i6). Afonso de Albuquerque: Corte, Cruzada e Império. Lisboa: Temas \& Debates.

Pigafetta, Antonio (I999). Relazione del primo viaggio attorno al mondo. Ed. Andrea Canova. Pádua: Editrice Antenore.

Pires, Tomé (20I7). Suma Oriental. Ed. Rui Manuel Loureiro. Lisboa: Centro Científico e Cultural de Macau.

Pissarra, José Virgílio Amaro (2002). Chaul e Diu, I508 e i509: O Domínio do Índico. Lisboa: Prefácio.

Pohle, Jürgen (2007). Martin Behaim (Martinho da Boémia): Factos, lendas e controvérsias. Coimbra: Centro Interuniversitário de Estudos Germanísticos.

Pohle, Jürgen (20I7). Os mercadores banqueiros alemães e a Expansão Portuguesa no reinado de D. Manuel I. Lisboa: Centro Humanidades, Faculdade de Ciências Sociais e Humanas, Universidade Nova de Lisboa; Universidade dos Açores.

Polo, Marco [et. al.] (1502). Marco Paulo. Ho liuro de Nycolao Veneto. Ho trallado da carta de hũ genoues das ditas terras. Lisboa: Valentim Fernandes.

Polo, Marco [et. al.] (1922). Marco Paulo. O Livro de Marco Paulo. O Livro de Nicolao Veneto. Carta de Jerónimo de Santo Estevam. Ed. Francisco Maria Esteves Pereira. Lisboa: Biblioteca Nacional. 
Racine, Matthew T. (2012). A Most Opulent Iliad: Expansion, Confrontation and Cooperation on the Southern Moroccan Frontier. San Diego: Lake George Press.

Ramos-Coelho, José (ed.) (1892). Alguns Documentos do Archivo Nacional da Torre do Tombo ácerca das Navegações e Conquistas Portuguezas. Lisboa: Imprensa Nacional.

Ramusio, Giovanni Battista (I978-ı988). Navigazioni e Viaggi. Ed. Marica Milanesi. Milão: Einaudi.

Ravenstein, E. G. (igo8). Martin Behaim: His Life and his Globe. Londres: George Philip \& Son, Ltd.

Rêgo, António da Silva (ed.) (I960-I977). As Gavetas da Torre do Tombo. Lisboa: Centro de Estudos Históricos Ultramarinos.

Rêgo, António da Silva [et al] (ed.) (1962-1989). Documentos sobre os Portugueses em Moçambique e na África Central. Lisboa: Centro de Estudos Históricos Ultramarinos / Instituto de Investigação Científica Tropical.

Rosa, Maria de Lurdes (r998). «D. Jaime, Duque de Bragança: Entre a Cortina e a Vidraça». Diogo Ramada Curto (ed.). O Tempo de Vasco da Gama. Lisboa: Comissão Nacional para as Comemorações dos Descobrimentos Portugueses; Difel, 319-332.

SÁnchez MARTínez, Antonio (2009). «De la "cartografía oficial” a la "cartografía jurídica”: la querella de las Molucas reconsiderada, I479-I529». Nuevo Mundo / Mundos Nuevos [em linha] [2 setembro 2018] <http://nuevomundo.revues.org/56899>.

Sánchez Martínez, Antonio (2013). La espada, la cruz y el Padrón: Soberanía, fe y representación cartográfica en el mundo ibérico bajo la Monarquía Hispánica, I503I598. Madrid: Consejo Superior de Investigaciones Científicas.

Sandman, Alison (2007). «Spanish Nautical Cartography in the Renaissance». David Woodward (ed.). History of Cartography. Volume Three: Cartography in the European Renaissance (Part I). Chicago; Londres: The University of Chicago Press, I095-II42.

Silva, Joaquim Candeias (1996). O Fundador do «Estado Português da Índia» D. Francisco de Almeida, I457(?)-I5ro. Lisboa: Comissão Nacional para as Comemorações dos Descobrimentos Portugueses; Imprensa Nacional-Casa da Moeda.

Sousa, Ivo Carneiro (2002). A Rainha D. Leonor (1485-1525): Poder, Misericórdia, Religiosidade e Espiritualidade no Portugal do Renascimento. Lisboa: Fundação Calouste Gulbenkian; Fundação para a Ciência e a Tecnologia.

Subrahmanyam, Sanjay (1993). The Portuguese in Asia, I500-1700: A Political and Economic History. Londres; Nova Iorque: Longman.

Thomaz, Luís Filipe (2000). Early Portuguese Malacca. Trad. Manuel Joaquim Pintado; Maria Pia Mozart Silveira. Macau: Comissão Territorial de Macau para as Comemorações dos Descobrimentos Portugueses; Instituto Politécnico de Macau.

Torpa, Helena Costa (I994). «Cataldo Sículo e o mecenato da rainha D. Leonor». Máthesis, 3, I67-197.

Abriu, 8 (2019): 35-67

ISSN: 2014-8526, e-ISSN: 20I4-8534 
VALiÉRe, Pierre (I976). Le voyage de Magellan raconté par un homme qui fut en sa compagnie. Paris: Fundação Calouste Gulbenkian.

VAn Duzer, Chet (2010). Johann Schöner's Globe of 1515: Transcription and Study. Filadélfia: American Philosophical Society.

Varthema, Ludovico de (I5Io). Itinerario. Roma: Stephano Guillireti de Loreno \& Hercule de Nani.

VARTHEMA, Ludovico de (I520). Itinerario del venerable varon Luis patricio romano. Trad. Cristóbal de Arcos. Sevilha: Jacob Cromberger.

Varthema, Ludovico de (2004). Voyage de Ludovico di Varthema en Arabie et aux Indes orientales (1503-1508). Trad. Paul Teyssier; ed. Luís Filipe Thomaz; Gilles Tarabout; Paul Teyssier; Gérard Troupeau. Paris: Éditions Chandeigne.

Vigneras, L. A. (1962). «The cartographer Diogo Ribeiro». Imago Mundi, i6-ı, 76-83.

Villas-Boas, Manuel (I988). Os Magalhães: Sete séculos de aventura. Lisboa: Editorial Estampa.

Villiers, John (2003). "AA truthful pen and an impartial spirit”: Bartolomé Leonardo de Argensola and the Conquista de las Islas Malucas». Renaissance Studies, I7-3, 449-473.

Viterbo, F. M. de Sousa (ig88). Trabalhos Náuticos dos Portugueses nos Séculos xVi e XVII. Ed. José Manuel Garcia. Lisboa: Imprensa Nacional-Casa da Moeda. 